\title{
Kontribusi Kecerdasan Emosional Dan Persepsi Sosial Terhadap Interaksi Sosial Mahasiswa Serta Implikasinya Dalam Bimbingan Dan Konseling
}

\author{
Monalisa $^{1}$, Daharnis ${ }^{2}$, Syahniar $^{3}$ \\ ${ }^{123}$ Universitas Negeri Padang
}

\begin{abstract}
The purpose of this research was obviously to describe: (1) emotional intelligence, (2) social perception, (3) social interaction, (4) the contribution of emotional intelligence, social perceptio, emotional intelligence and social perception towards social interactions. This research was using quantitative method with correlation type. The population was college students' guidance and counseling program in STKIP PGRI West Sumatera. The research findings shown that: (1) an average of the emotional intelligence of college students at the high category, (2) social perceptions of the college students were in the positive category, (3) college students' social interaction were in the good category, (4) there was a significant contribution of emotional intelligence toward social interaction, (5) there was a significant contribution of social perception toward social interaction, and (6) there were together a significant contribution of emotional intelligence and social perception toward social interaction
\end{abstract}

Keywords: Emotional Intelligence, Social Perception, Social Interaction Indonesian Institute for Counseling, Education and Therapy (IICET).

\section{PENDAHULUAN}

Manusia adalah makhluk sosial yang dapat berinteraksi satu sama lain. Sepanjang rentang kehidupan yang dijalani, dari lahir hingga tutup usia manusia membutuhkan orang lain. Bermacammacam cara dalam proses interaksi akan banyak ditemui sepanjang manusia menjalani kehidupannya. Satu pribadi dengan pribadi lainnya, satu lingkungan dengan lingkungan lainnya akan memiliki cara yang berbeda dalam berinteraksi.

Semakin tinggi tingkat pendidikan, akan membuat seseorang berada pada lingkungan yang lebih luas. Perguruan tinggi merupakan lembaga pendidikan tertinggi yang dapat ditempuh oleh seseorang. Belajar di perguruan tinggi akan mempertemukan individu-individu yang berasal dari latar belakang berbeda. Memenuhi tugas dan tanggung jawab sebagai mahasiswa tentu membutuhkan kehadiran orang lain. Bertemu dengan individu baru, pada umumnya berasal dari latar belakang pendidikan, kampung halaman, budaya, agama dan bahasa yang berbeda menjadi masalah tersendiri yang dialami mahasiswa. Perbedaan tersebut tentu akan menimbulkan hal yang positif bila mahasiswa mampu mengatasinya dengan baik. Sebaliknya, akan menimbulkan hal yang negatif bila tidak mampu menanggapinya dengan baik. Dampak negatif dari perbedaan itu dapat diminimalisir apabila mahasiswa mampu menjalin interaksi sosial yang baik dengan lingkungannya. 
Interaksi sosial yang dialami mahasiswa tentu tidak hanya interaksi sosial biasa, haruslah berkualitas dan dapat bermanfaat bagi orang lain. Interaksi sosial menurut Newcomb, Turner, dan Converse (1985:18) adalah kumpulan tingkah laku yang dapat diamati, yang terjadi antara dua atau lebih dari dua individu. Menurut Bonner (dalam Ahmadi, 2007:49) interaksi sosial adalah suatu hubungan antara dua individu atau lebih, di mana kelakuan individu yang satu mempengaruhi, mengubah, atau memperbaiki kelakuan individu yang lain atau sebaliknya. Berdasarkan pendapat tersebut, maka dapat disimpulkan bahwa interaksi sosial adalah kumpulan tingkah laku individu yang akan membentuk hubungan antara satu individu dengan individu lainnya di mana hubungan tersebut dapat memperbaiki, mengubah atau mempengaruhi individu lainnya.

Interaksi sosial akan berbeda pada setiap lingkungan yang dilalui oleh mahasiswa. Warsito (dalam Sumiyatun, 2003:144) menyatakan bahwa pertemuan beberapa kelompok dapat membuahkan hal yang bersifat positif dan negatif sebagai perwujudan dari interaksi sosial.

Al-Munawir (dalam Muslim, 2013:484) menyatakan bahwa manusia adalah individu yang selalu ingin melakukan kerjasama dan interaksi sosial. Lebih lanjut, Muslim (2013:484) menyatakan bahwa interaksi tersebut tidak hanya dipicu oleh dorongan kebutuhan ekonomis, biologis, emosional, dan sebagainya yang mengikat dirinya, melainkan juga sebagai fitrah yang tidak terbantahkan pada dirinya. Mengutip pendapat tersebut, diketahui bahwa interaksi sosial yang terjadi salah satunya dipengaruhi oleh kecerdasan emosional seseorang.

Menurut Ma'sum (dalam Yunistiati, Djalali, dan Farid, 2014:80) bahwa interaksi sosial dipengaruhi oleh pola asuh demokratis, lintas budaya, model kepribadian, regulasi emosi, rasionalitas, hubungan sosial yang diharapkan, pembangunan sosial yang diharapkan dan pemikiran sosial. Penelitian yang dilakukan oleh Lopes, Brackett, Nezlek, Shiitz, Sellin, dan Salovey (2004) diketahui bahwa kecerdasan emosional yang dimiliki seseorang memiliki pengaruh yang positif terhadap kualitas interaksi sosialnya. Sementara itu, Irwanto, Elia, Hadisoepadmo, Priyani, Wismanto, dan Fernandes (2002:258) menyatakan bahwa salah satu faktor yang sangat mempengaruhi interaksi sosial adalah persepsi sosial.

Berdasarkan pendapat tersebut, jelaslah bahwa banyak faktor yang mempengaruhi interaksi sosial, dua diantaranya adalah kecerdasan emosional dan persepsi sosial seseorang. Namun, untuk mengetahui seberapa besar kontribusi yang diberikan oleh dua faktor tersebut (kecerdasan emosinal dan persepsi sosial) terhadap interaksi sosial perlu dilakukan penelitian.

Tujuan penelitian ini adalah untuk mendeskripsikan: (1) kecerdasan emosional mahasiswa Program Studi Bimbingan dan Konseling STKIP PGRI Sumatera Barat, (2 persepsi sosial mahasiswa Program Studi Bimbingan dan Konseling STKIP PGRI Sumatera Barat, (3) interaksi sosial mahasiswa Program Studi Bimbingan dan Konseling STKIP PGRI Sumatera Barat, (4) kontribusi kecerdasan emosional terhadap interaksi sosial mahasiswa Program Studi Bimbingan dan Konseling STKIP PGRI Sumatera Barat, (5) kontribusi persepsi sosial terhadap interaksi sosial mahasiswa Program Studi Bimbingan dan Konseling STKIP PGRI Sumatera Barat, dan (6) kontribusi kecerdasan emosional dan persepsi sosial secara bersama-sama terhadap interaksi sosial mahasiswa Program Studi Bimbingan dan Konseling STKIP PGRI Sumatera Barat.

\section{METODE}

Penelitian ini menggunakan metode kuantitatif jenis deskriptif korelasional. Populasi penelitian adalah mahasiswa Program Studi Bimbingan dan Konseling STKIP PGRI Sumatera Barat yang bejumlah 818 mahasiswa, dengan sampel 272 mahasiswa yang dipilih dengan teknik proportional stratified random sampling. Instrumen yang digunakan adalah skala model Likert. Untuk mengetahui kontribusi variabel bebas terhadap variabel terikat, maka data dianalisis dengan regresi sederhana dan regresi ganda. Analisis data dibantu dengan menggunakan program SPSS versi 20.0 . 
HASIL

Deskripsi Data

Data dalam penelitian ini meliputi variabel kecerdasan emosional (X1), persepsi sosial (X2), dan interaksi sosial (Y). Berikut ini dikemukakan deskripsi data hasil penelitian.

\section{Kecerdasan Emosional $\left(\mathbf{X}_{1}\right)$}

Secara keseluruhan jumlah item pernyataan variabel locus of control ada sebanyak 24 butir item, rentangan skor dari 1-5, dengan skor tertinggi adalah 120 dan skor terendah adalah 24 . Kriteria skala locus of control yang berjumlah 243 responden dapat dilihat pada Tabel 1.

Tabel 1. Distribusi Frekuensi dan Persentase Kecerdasan Emosional $\left(\mathbf{X}_{1}\right)$

\begin{tabular}{cccc}
\hline Interval Skor & Kategori & Frekuensi & \% \\
& & & \\
\hline $\mathbf{2 8 4}$ & Sangat Tinggi & 24 & 8,82 \\
$\mathbf{6 8}-\mathbf{8 3}$ & Tinggi & 213 & 78,31 \\
$\mathbf{5 2}-\mathbf{6 7}$ & Sedang & 35 & 12,87 \\
$\mathbf{3 6}-\mathbf{5 1}$ & Rendah & 0 & 0 \\
$\leq \mathbf{3 5}$ & Sangat Rendah & 272 & 0 \\
& Total & & 100 \\
\hline
\end{tabular}

Tabel 1 memperlihatkan bahwa mahasiswa program studi bimbingan dan konseling STKIP PGRI Sumatera Barat memiliki kecerdasan emosional yang tinggi. Namun demikian, masih terdapat variasi skor kecerdasan emosional pada mahasiswa tersebut.

\section{Persepsi Sosial $\left(\mathbf{X}_{2}\right)$}

Hasil pengumpulan dan pengolahan data dengan instrumen persepsi sosial dari keseluruhan sampel yang berjumlah 272 mahasiswa, dapat dilihat pada Tabel 2.

Tabel 2. Distribusi Frekuensi dan Persentase Persepsi Sosial $\left(\mathbf{X}_{2}\right)$

\begin{tabular}{cccc}
\hline Interval Skor & Kategori & Frekuensi & \% \\
\hline $\mathbf{2 6 3}$ & Sangat Positif & 1 & 0,37 \\
$\mathbf{5 1}-\mathbf{6 2}$ & Positif & 67 & 24,63 \\
$\mathbf{3 9}-\mathbf{5 0}$ & Cukup Positif & 192 & 70,59 \\
$\mathbf{2 7}-\mathbf{3 8}$ & Tidak Positif & 12 & 4,41 \\
$\leq \mathbf{2 6}$ & Sangat Tidak Positif & 0 & 0 \\
& Total & 272 & 100 \\
\hline
\end{tabular}

Tabel 2 memperlihatkan bahwa sebagian besar mahasiswa memiliki persepsi sosial yang cukup positif tentang orang lain.

3. Interaksi Sosial Mahasiswa (Y)

Hasil pengumpulan dan pengolahan data melalui instrumen interaksi sosial dari keseluruhan sampel berjumlah 272 mahasiswa, dapat dilihat pada Tabel 3. 
Tabel 3. Distribusi Frekuensi dan Persentase Interaksi Sosial (Y)

\begin{tabular}{cccc}
\hline Interval Skor & Kategori & Frekuensi & \% \\
\hline $\mathbf{6 1}-\mathbf{7 5}$ & Baik & 187 & 68,75 \\
$\mathbf{4 7 - 6 0}$ & Cukup Baik & 58 & 21,32 \\
$\mathbf{3 3}-\mathbf{4 6}$ & Tidak Baik & 1 & 0,37 \\
$\leq \mathbf{3 2}$ & Sangat Tidak Baik & 0 & 0 \\
& & 272 & 100 \\
\hline
\end{tabular}

Tabel 3 memperlihatkan bahwa mutu interaksi sosial mahasiswa program studi bimbingan dan konseling STKIP PGRI Sumatera Barat sudah baik. Namun, masih terdapat variasi pada mutu interaksi sosial ini. Variasi skor tersebut tentu perlu untuk diperhatikan agar semua mahasiswa dapat membangun interaksi sosial dengan mutu yang baik bahkan sangat baik.

\section{Pengujian Persyaratan Analisis Data}

Uji persyaratan analisis yang dilakukan pada data penelitian ini adalah uji normalitas, uji linieritas, dan uji multikolinieritas.

\section{Uji Normalitas}

Uji normalitas dengan menggunakan metode Kolmogorov-Smirnov menunjukkan bahwa data variabel penelitian berdistribusi normal, dengan nilai Asymp. Sig. variabel kecerdasan emosional sebesar 0,118 , persepsi sosial sebesar 0,130, dan interaksi sosial sebesar 0,264.

\section{Uji Linieritas}

Hasil uji linieritas menunjukkan bahwa data variabel kecerdasan emosional dengan interaksi sosial adalah linier dengan nilai Fhitung $(24,286)>$ Ftabel $(3,89)$. Data variabel persepsi sosial dengan interaksi sosial juga linier dengan Fhitung $(16,023)>$ Ftabel $(3,89)$.

\section{Uji Multikolinieritas}

Hasil uji multikolinieritas menunjukkan bahwa tidak terjadi multikolinieritas antara variabel kecerdasan emosional dengan persepsi sosial, dengan nilai VIF kecerdasan emosional sebesar 1,114 dan nilai VIF persepsi sosial sebesar $1,114<5$.

\section{Kontribusi Kecerdasan Emosional dan Persepsi Sosial terhadap Interaksi Sosial}

\section{Hubungan Kontribusi Kecerdasan Emosional terhadap Interaksi Sosial}

Hasil analisis kontribusi kecerdasan emosional terhadap interaksi sosial dapat dilihat pada Tabel 4.

Tabel 4. Hasil Analisis Regresi Sederhana dan Uji Signifikansi $X_{1}$ terhadap $Y$

\begin{tabular}{cccc}
\hline Model & $\mathbf{R}$ & $\boldsymbol{R}$ Square & Sig. \\
\hline $\mathbf{X}_{\mathbf{1}} \mathbf{- Y}$ & 0,290 & 0,084 & 0,000 \\
\hline
\end{tabular}

Pada Tabel 4 menunjukkan bahwa kecerdasan emosional berkontribusi secara signifikan terhadap interaksi sosial sebesar $8,4 \%$.

\section{Persepsi Sosial terhadap Interaksi Sosial} 5.

Hasil analisis kontribusi persepsi sosial terhadap interaksi sosial dapat dilihat pada Tabel 
Tabel 5. Hasil Analisis Regresi Sederhana dan Uji Signifikansi $\mathbf{X}_{2}$ terhadap $\mathbf{Y}$

\begin{tabular}{cccc}
\hline Model & $\mathbf{R}$ & $\boldsymbol{R}$ Square & Sig. \\
\hline $\mathbf{X}_{2}-\mathbf{Y}$ & 0,235 & 0.055 & 0,000 \\
\hline
\end{tabular}

Pada Tabel 5 menunjukkan bahwa persepsi sosial berkontribusi secara signifikan terhadap interaksi sosial sebesar 5,5\%.

\section{Kontribusi Kecerdasan Emosional dan Persepsi Sosial terhadap Interaksi Sosial}

Hasil analisis kontribusi kecerdasan emosional dan persepsi sosial terhadap interaksi sosial dapat dilihat pada Tabel 6.

Tabel 6. Hasil Analisis Regresi Ganda dan Uji Signifikansi $X_{1}$ dan $X_{2}$ terhadap $Y$

\begin{tabular}{|c|c|c|c|}
\hline Model & $\mathbf{R}$ & R Square & Sig. \\
\hline $\mathbf{X}_{1}, \mathbf{X}_{2}-\mathbf{Y}$ & 0,326 & 0,106 & 0,000 \\
\hline
\end{tabular}

Pada Tabel 6 dapat dilihat bahwa secara bersama-sama kecerdasan emosional dan persepsi sosial berkontribusi secara signifikan terhadap interaksi sosial sebesar 10,6\%.

\section{PEMBAHASAN}

\section{Kecerdasan Emosional}

Hasil analisis data penelitian menunjukkan bahwa, secara rata-rata kecerdasan emosional mahasiswa berada pada kategori tinggi. Hal ini berarti, kemampuan mahasiswa dalam mengelola emosinya sudah baik. Berdasarkan pencapaian masing-masing indikator, yaitu: indikator kesadaran diri, pengendalian diri, motivasi diri, empati dan membina hubungan dengan orang lain berada pada kategori tinggi.

Secara umum, kecerdasan emosional merupakan salah satu aspek keberhasilan individu diberbagai lini kehidupan. Hal tersebut sesuai dengan pendapat Mashar (2011:65) yang menyatakan bahwa kemampuan individu dalam mengembangkan kecerdasan emosionalnya berkorelasi positif dengan keberhasilan akademis, sosial, dan kesehatan mentalnya. Bila dikaitkan dengan kehidupan mahasiswa saat ini, tuntutan pentingnya memiliki kecerdasan emosional dalam kehidupan sehari-hari sangatlah tinggi. Kemampuan mahasiswa dalam mengenali diri mereka sendiri, mengatur suasana hati, memotivasi diri sendiri, merasakan apa dan bagaimana orang lain di sekitar mereka, serta dalam membina hubungan dengan orang lain akan memberikan banyak keuntungan untuk diri mereka secara pribadi, dan juga diri mereka sebagai makhluk sosial.

Pentingnya setiap individu memiliki kecerdasan emosional akan memberikan dampak yang positif bagi individu tersebut dalam kehidupannya sehari-hari. Individu yang cerdas dalam mengelola emosinya akan memiliki suasana hati yang bahagia, mereka mampu dengan tepat bagaimana bersikap dengan orang lain. Bar-on (dalam Artha dan Supriadi, 2013:193) menyatakan bahwa orang cerdas secara emosi cenderung untuk lebih optimis, fleksibel, lebih realistis, dan mampu mengatasi masalah serta menghadapi tekanan.

Tanpa adanya kecerdasan emosional, akan membuat mahasiswa mudah untuk pustus asa, sulit menghadapi berbagai permasalah yang ada, dan tentunya akan menghambat mahasiswa itu sendiri dalam menjalankan aktifitasnya sehari-hari. Tugade dan Fredrickson (dalam Mashar, 2011:73) menyatakan bahwa individu yang mampu mengembangkan emosi positif dalam diri terbukti lebih berhasil mengatasi permasalahan hidup sehingga dapat menjadi individu yang lebih resilent, berprestasi, dan bahagia. 
Menumbuhkan dan mengembangkan kecerdasan emosional mahasiswa tentu tidak hanya menjadi tugas dan tanggung jawab mereka secara pribadi, tapi tentu juga lingkungan mereka. Kampus sebagai wadah tempat mereka dalam memperkaya khasanah intelektual, menerima dan memberikan nilai-nilai kehidupan juga berperan dalam konteks ini. Berdasakan hasil penelitian ini dapat dipahami bahwa perlu kiranya layanan bimbingan dan konseling di perguruan tinggi. Melalui layanan bimbingan dan konseling di perguruan tinggi hendaknya dapat membantu mahasiswa dalam melatih, mengembangkan dan meningkatkan kecerdasan emosional mahasiswa itu sendiri. Salah satu layanan yang dapat dibeikan untuk meningkatkan kecedasan emosional mahasiswa adalah layanan bimbingan kelompok (Mulyani, 2012; Sumarlin, 2013).

\section{Persepsi Sosial}

Berdasarkan hasil analisis data penelitian, secara rata-rata persepsi sosial mahasiswa berada pada kategori cukup positif. Dilihat dari pencapaian pada masing-masing indikator diketahui bahwa, pada indikator aspek fisik dan aspek sosial-kultural berada pada kategori positif. Persepsi sosial mahasiswa pada indikator aspek psikologis dan aspek spiritual berada pada kategori cukup positif.

Pesepsi sosial menurut Calhoun dan Acocella (1990:280) adalah pandangan seseorang tentang orang lain. Sesuai dengan pendapat tesebut, Irwanto, Elia, Hadisoepadmo, Priyani, Wismanto, dan Fernandes, (2002:259) mendefinisikan persepsi sosial sebagai penilaian tentang aspek fisik (physical appearance) dan ciri-ciri perilaku orang lain. Kemampuan mahasiswa dalam memandang dengan positif orang lain merupakan hal yang penting untuk dikembangkan. Pandangan/penilaian yang tertanam pada kognitif seseorang akan tewujud pada cara seseorang bersikap yang pada akhirnya terwujud dalam bentuk tindakan. Tindakan ini pada akhirnya akan membentuk interaksi dengan orang lain. Ketepatan dalam mempersepsi akan menghasilkan hubungan yang baik dan bahagia, namun sebaliknya, ketidaktepatan dalam mempersepsi akan menimbulkan permasalahan yang pada akhirnya akan membuat hubungan menjadi tidak bahagia.

Sobur (2013: 476) menyatakan bahwa tanggapan ataupun respon seorang individu terhadap orang lain atau objek diluar dirinya dibentuk oleh cara orang tersebut "memandang" seseorang atau objek tersebut. Dapat dimaknai bahwa, bagaimana penilaian seseorang tentang orang lain akan menentukan bagaimana orang tersebut bersikap terhadap orang lain.

\section{Interaksi Sosial}

Hasil analisis data penelitian menunjukkan bahwa secara keseluruhan rata-rata kualitas interaksi sosial berada pada kategori baik. Namun, bila dilihat perindikator dalam variabel interaksi sosial masih terdapat mahasiswa yang memiliki mutu interaksi sosial yang cukup baik. Hal ini terlihat pada indikator kerja sama. Pada item no 2, yaitu "saya kurang bisa bekerjasama dengan kelompok yang ditentukan dosen". Hal ini menunjukkan bahwa masih ada mahasiswa yang belum dapat membangun hubungan yang baik dengan siapa saja. Dapat dikatakan bahwa, masih ada mahasiswa yang memilih-milih teman dalam hal tertentu. Sehingga, pada saat pembentukan kelompok oleh dosen, masih ada yang kurang dapat bekerjasama didalam kelompok tesebut.

Pentingnya membangun interaksi yang baik dengan siapa saja tentu akan menguntungkan kedua belah pihak. Melalui interaksi yang baik seseorang dapat mengaktualisasikan dirinya dangan baik. Pada akhirnya apa yang diharapkan dalam hubungan dengan orang lain dapat tercapai. Interaksi sosial yang dibangun dengan kualitas yang baik, akan berdampak kepuasan terhadap hubungan itu sendiri dan keberlangsungan hubungan itu sendiri. Namun sebaliknya, apabila kualitas interaksi sosial itu buruk, tentu rasa kecewa akan muncul dan kecil kemungkinan hubungan tersebut dapat belangsung lama.

Yunistiati, Djalali, dan Farid (2014:78) menyatakan bahwa apabila seseorang tidak memiliki kemampuan untuk berinteraksi sosial atau bahkan tidak dapat berinteraksi, disadari atau tidak, seseorang akan kehilangan relasinya. Dapat dimaknai bahwa, mahasiswa yang 
tidak memiliki kemampuan dalam berinteraksi akan kehilangan relasinya. Padahal, idealnya mahasiswa haruslah memiliki kemampuan dalam berinteraksi sosial.

Melihat hal tersebut, diketahui bahwa pentingnya pelayanan bimbingan dan konseling di perguruan tinggi, khususnya terkait dengan pengembangan kemampuan mahasiswa dalam berinteraksi sosial. Pelaksanaan layanan bimbingan dan konseling di perguruan tinggi dapat dilakukan untuk mengembangkan kemampuan mahasiswa dalam interaksi sosial.

\section{Kontribusi Kecerdasan Emosional terhadap Interaksi Sosial}

Hasil penelitian menunjukkan bahwa kecerdasan emosional berkontribusi secara signifikan terhadap interaksi sosial. Temuan ini diperoleh berdasarkan hasil analisis data yang menunjukkan bahwa kontribusi kecerdasan emosional terhadap interaksi sosial sebesar 8,4\%. Artinya, kecerdasan emosional merupakan salah satu faktor yang berkontribusi terhadap interaksi sosial. Kemampuan seseorang dalam mengelola suasana hatinya akan menentukan bagaimana seseorang tersebut bersikap yang pada akhirnya akan membuat suatu interaksi dengan orang lain. Karena, kebanyakan orang hanya bersedia menolong orang lain saat perasaan hatinya sedang baik dari pada saat perasaan hatinya tidak baik, (Baron, Berkowitz dalam Baron dan Byrne, 2004:39).

Lopes, Salovey, Cote dan Beers (2005:113) menyatakan bahwa "One inappropriate outburst of anger can destroy a relations forever". Hal tersebut dapat dimaknai bahwa, salah satu ledakan kemarahan yang tidak tepat dapat menghancurkan hubungan selamanya. Terlihat bahwa, kecerdasan emosional seseorang berdampak terhadap hubungan orang itu sendiri.

Terjalinnya suatu interaksi sosial yang berkualitas tentu banyak faktor yang mempengaruhinya, salah satunya adalah kecerdasan emosional. Goleman (2007:48) menyatakan bahwa orang yang cakap secara emosional, mengetahui dan dapat dengan baik menangani perasaan mereka sendiri, serta mampu dengan tepat menghadapi perasaan orang lain, memiliki keuntungan dalam setiap bidang kehidupan, entah itu dalam hubungan asmara dan persahabatan yang mereka jalin, ataupun dalam menangkap aturan-aturan tidak tertulis yang menentukan keberhasilan dalam politik organisasi. Dapat dikatakan bahwa, seseorang yang memiliki dan dapat mengembangkan dengan baik kecerdasan emosionalnya mampu membangun hubungan yang baik dengan orang lain, apakah hubungan tersebut dinamakan hubungan asmara, pertemanan, persahabatan ataupun dengan kolega dalam kegiatan politik organisasi yang mereka geluti.

Hasil penelitian ini juga sesuai dengan pendapat Lopes, Salovey, Cote, dan Beers (2005:113) yang menyatakan bahwa kemampuan seseorang dalam mengelola emosinya memainkan peranan penting dalam interaksi sosial seseorang. Lopes, Salovey, Cote, dan Beers (2005:113) juga menyatakan bahwa "Emotion regulated ability correlated significantly with four out of eight indicators of the quality of sosial interactions". Berdasarkan pendapat tersebut, jelaslah bahwa kecerdasan emosional seseorang memberikan kontribusi terhadap interaksi sosialnya.

\section{Kontribusi Persepsi Sosial terhadap Interaksi Sosial}

Hasil penelitian menunjukkan bahwa persepsi sosial berkontribusi secara signifikan terhadap interaksi sosial mahasiswa. Temuan ini diperoleh berdasarkan rangkaian analisis data yang menunjukkan bahwa kontribusi persepsi sosial terhadap interaksi sosial sebesar 5,5\%. Artinya, persepsi sosial merupakan salah satu faktor yang berkontribusi terhadap interaksi sosial.

Merujuk pada data hasil penelitian ini dapat dipahami bahwa semakin positif persepsi seseorang semakin baik pula kualiatas/mutu dari interaksi sosial yang dibangun. Interaksi sosial adalah hubungan antara satu individu dengan individu lainnya, maupun satu kelompok dengan kelompok lainnya. Hal ini sesuai dengan pendapat Satrbuck dan Mezias (dalam Hanurawan, 2010:34) bahwa dengan persepsi sosial seseorang berupaya memahami orang lain ataupun suatu realitas sosial. 
Pandangan/penilaian yang baik tentang orang lain akan membuat seseorang bersikap lebih terbuka dan lebih baik dalam berinteraksi. Karena, ketika seseorang berfikiran yang kurang baik tentang orang lain, akan membuat seseorang lebih berhati-hati dalam berinteraksi. Hal ini sesuai dengan pendapat Baron dan Byrne (2004:71) yang menyatakan bahwa "beberapa orang merasa tidak nyaman berada dalam situasi sosial karena mereka cenderung khawatir tentang bagaimana penilaian orang lain". Buytendijk (dalam Dijksterhuis dan Bargh, 2001:4) menyatakan bahwa "....perception always include to action". Dapat dimaknai bahwa, persepsi yang dimiliki seseorang akan menyertakan tindakan seseorang. Hal yang menjadi penilaian sendiri pada orang lain, akan ikut mempengaruhi bagaimana tindakan yang akan dilakukan selanjutnya. Tindakan ini pada akhirnya akan menjadi interaksi satu sama lain.

Lebih lanjut, Ferguson dan Bargh (2004:33) melakukan kajian mengenai "How social perception can automatically influence behavior". Berdasarkan kajian tersebut, diketahui bahwa bagaimana seseorang menilai tentang orang lain akan mempengaruhi bagaimana orang berperilaku terhadap orang lain. Pengetahuan atau penilaian yang dimiliki seseorang tentang suatu hal akan mempengaruhi bagaimana orang berperilaku terhadap hal tersebut.

\section{Kontribusi Kecerdasan Emosional dan Persepsi Sosial terhadap Interaksi Sosial}

Hasil penelitian menunjukkan bahwa kecerdasan emosional dan persepsi sosial secara bersama-sama berkontribusi secara signifikan terhadap interaksi sosial. Temuan ini diperoleh berdasarkan rangkaian analisis data yang menunjukkan bahwa kontribusi kecerdasan emosional dan persepsi sosial secara bersama-sama terhadap interaksi sosial sebesar $10,6 \%$. Artinya, kecerdasan emosional dan persepsi sosial merupakan faktor yang berkontribusi terhadap interaksi sosial.

Apabila ditelaah lebih dalam lagi, kontribusi yang diberikan oleh kecerdasan emosional dan persepsi sosial terhadap interaksi sosial lebih besar bila bersama-sama dibandingkan dengan kontribusinya secara sendiri. Hal ini berarti, mahasiswa yang memiliki kecerdasan emosional yang tinggi dan dibarengi dengan adanya persepsi sosial yang positif tentang orang lain, akan memiliki kualitas interaksi sosial yang lebih baik lagi. Dapat juga dikatakan bahwa, ketika mahasiswa memiliki kesadaran akan dirinya sendiri, mampu mengendalikan diri, memotivasi diri, dan berempati, serta kemampuan dalam membina hubungan yang tinggi, juga memiliki penilaian yang positif terhadap aspek fisik, psikologis, sosial-kultural, dan spiritual orang lain akan memiliki kualitas interaksi sosial yang sangat baik.

Tentu, setiap orang menginginkan hubungan yang terjalin dengan orang lain, apakah teman, sahabat, mita kerja, ataupun kekasih, akan memiliki mutu yang baik dan menimbulkan kepuasan serta kebahagiaan. Maka, perlu kiranya setiap orang mengembangkan kecerdasan emosional yang tinggi dan persepsi sosial yang positif tentang orang lain. Pengembangan kecerdasan emosional dan persepsi sosial oleh mahasiswa tentu perlu kiranya peran bimbingan dan konseling di perguruan tinggi.

Adanya pelayanan bimbingan dan konseling di perguruan tinggi dapat membantu mahasiswa dalam meningkatkan kecerdasan emosional bagi mahasiswa yang memiliki skor rendah, dan bagi mahasiswa yang memiliki skor tinggi dapat mempertahankan serta mengembangkan kecerdasan emosionalnya. Begitupun pada persepsi sosial, mahasiswa yang masih memiliki persepsi yang kurang positif tentang orang lain, melalui layanan bimbingan dan konseling dapat membantu mahasiswa untuk mengubah persepsi ke arah yang positif. Sehingga, dengan adanya kecerdasan emosional yang tinggi dan persepsi sosial yang positif, mahasiswa memiliki mutu interaksi sosial yang lebih baik lagi.

\section{KESIMPULAN}

Berdasarkan temuan dan pembahasan hasil penelitian, maka dapat dikemukakan kesimpulan sebagai berikut:

1. Secara rata-rata kecerdasan emosional mahasiswa bimbingan dan konseling STKIP PGRI Sumatera Barat berada pada kategori tinggi. 
2. Secara rata-rata persepsi sosial mahasiswa bimbingan dan konseling STKIP PGRI Sumatera Barat berada pada kategori cukup positif.

3. Secara rata-rata interaksi sosial mahasiswa bimbingan dan konseling STKIP PGRI Sumatera Barat berada pada kategori baik.

4. Kecerdasan emosional memberikan kontribusi secara signifikan terhadap interaksi sosial mahasiswa bimbingan dan konseling STKIP PGRI Sumatera Barat sebesar 8,4\%.

5. Persepsi sosial memberikan kontribusi secara signifikan terhadap interaksi sosial mahasiswa bimbingan dan konseling STKIP PGRI Sumatera Barat sebesar 5,5\%.

6. Kecerdasan emosional dan persepsi sosial secara bersama-sama memberikan kontribusi terhadap interaksi sosial mahasiswa bimbingan dan konseling STKIP PGRI Sumatera Barat sebesar $10,6 \%$. Artinya tinggi rendahnya interaksi sosial tidak hanya dipengaruhi satu variabel saja (kecerdasan emosional atau persepsi sosial), namun dipengaruhi secara bersama-sama oleh kecerdasan emosional dan persepsi sosial. Dalam arti lain dapat dinyatakan bahwa semakin tinggi kecerdasan emosional dan semakin positif persepsi sosial, maka semakin baik mutu interaksi sosial mahasiswa Program Studi Bimbingan dan Konseling STKIP PGRI Sumatera Barat. Hal ini berarti variabel kecerdasan emosional dan persepsi sosial akan lebih efektif jika dikombinasikan secara bersama-sama sebagai prediktor interaksi sosial daripada hanya satu variabel saja. Secara sendiri-sendiri kecerdasan emosional paling efektif memberikan kontribusi terhadap interaksi sosial dibandingkan persepsi sosial.

\section{SARAN}

Berdasarkan hasil penelitian, pembahasan, dan kesimpulan yang telah dikemukakan sebelumnya, maka terdapat beberapa saran yang dapat direkomendasikan sebagai berikut:

1. Ketua STKIP PGRI Sumatera Barat

Hasil penelitian ini, dapat menjadi perhatian tentang pentingnya pelayanan bimbingan dan konseling di perguruan tinggi. Untuk itu, mengingat saat ini STKIP PGRI Sumatera Barat belum memiliki Unit Pelayanan Bimbingan dan Konseling (UPBK) perlu kiranya hal ini menjadi perhatian.

2. Pimpinan dan Dosen Program Studi Bimbingan dan Konseling

Hasil penelitian ini dapat dijadikan acuan dalam proses perkuliahan, baik itu dalam menetapkan metode yang digunakan maupun hal-hal lain yang dapat mengembangkan dan meningkatkan aspek kecerdasan emosional mahasiswa serta persepsi sosial mahasiswa agar mahasiswa memiliki mutu interaksi sosial yang lebih baik lagi kedepannya. Sehingga, mahasiswa bimbingan dan konseling dapat menjadi role model bagi mahasiswa lainnya.

\section{DAFTAR RUJUKAN}

Ahmadi, A. (2007). Psikologi Sosial. Jakarta: Rineka Cipta.

Artha, N.M.W.I., dan Supriadi. (2013). "Hubungan antara Kecerdasan Emosi dan Self Efficacy dalam Pemecahan Masalah Penyesuaian Diri Remaja Awal". Jurnal Psikologi Udayana. Vol. 1, 190-202.

Baron, R.A, dan Byrne, D. (2004). Social Psychology. Understanding Human Interaction. Boston: Allyn and Bacon, Incorporation.

Calhoun, J.F., dan Acocella, Y.R. (1990). Psychology of Adjusment and Human Relationship. New Yok: Mc Graw-Hill.

Dijksterhuis, A.P., dan Bargh, J.A., (2001). "The Perception-Behavior Expressway: Automatic Effects of Social Perception on Social Behavior". Experimental Social Psychology. Volume 33. 1-40.

Ferguson, M.J., dan Bargh, J.A. (2004). "How Social Perception Can Automatically Influence Behavior". TRENDS in Cognition Science. Vol.8 No1.33-39. 
Goleman, D. (2007). Emotional Intelligence, Mengapa EI Lebih Penting dari pada IQ. (Alih Bahasa: T. Hermaya). Jakarta: Gramedia Pustaka Utama.

Hanurawan, F. (2010). Psikologi Sosial “Suatu Pengantar”. Bandung: Rosda.

Irwanto, Elia, H., Hadisoepadmo, A., Priyani, R., Wismanto, Y.B., dan Fernandes, C. (2002). Psikologi Umum (Buku Panduan Mahasiswa). Jakarta: Prenhallindo.

Lopes, P.N., Brackett, M.A., Nezlek, J.B., Schiitz, A., Sellin, I., dan Salovey, P. (2004). "Emotional Intelligence and Social Interaction". Personality and Social Psychology Bulletin. 30. 10181034.

Lopes, P.N., Salovey, P., Cote, S., dan Beers, M. (2005). "Emotion Regulation Abilities and the Quality of Social Interaction". Brief Reports American Psychological Association. 113118 .

Mashar, R. (2011). Emosi Anak Usia Dini dan Strategi Pengembangannya. Jakarta: Kencana Prenada Media Group.

Mulyani, S. (2012). "Upaya Meningkatkan Kecerdasan Emosional Melalui Bimbingan Kelompok pada Siswa”. Jurnal Ilmiah Pendidikan Bimbingan dan Konseling. (94-95).

Muslim, A. (2013). "Interaksi Sosial dalam Masyarakat Multietnis". Jurnal Diskursus Islam. Volume 1 Nomor 3. Desember 2013.

Newcomb, T.M., Turner, R.H., dan Converse, P.E. (1985). Social Psychology: The Studi of Human Interaction. (Alih Bahasa: Tim Fakultas Psikologi Universitas Indonesia). Bandung: Diponegoro.

Sumarlin, (2013). "Model Bimbingan Kelompok Berbasis Nilai Budaya Muna untuk Meningkatkan Kecerdasan Emosional Siswa”. Jurnal Bimbingan dan Konseling. 2 (2). 116-123.

Sumiyatun. (2003). "Interaksi Sosial Etnis Jawa dengan Penduduk Asli Lampung (Studi tehadap Masyarakat Kota Metro, Provinsi Lampung)". Tesis tidak diterbitkan. Padang: Pogram Pascasarjana UNP.

Yunistiati, F., Djalali, M.A., dan Farid, M. (2014). "Keharmonisan Keluarga, Konsep Diri, dan Interaksi Sosial Remaja”. Personal, Jurnal Psikologi Indonesia. Vol 3, No.01. 71-82. 